TTR

Traduction, terminologie, re?daction

\title{
Translation, Heterogeneity, Linguistics
}

\section{Lawrence Venuti}

Volume 9, numéro 1, 1er semestre 1996

Le festin de Babel

Babel's Feast

URI : https://id.erudit.org/iderudit/037240ar

DOI : https://doi.org/10.7202/037240ar

Aller au sommaire du numéro

\section{Éditeur(s)}

Association canadienne de traductologie

ISSN

0835-8443 (imprimé)

1708-2188 (numérique)

Découvrir la revue

Citer cet article

Venuti, L. (1996). Translation, Heterogeneity, Linguistics. TTR, 9(1), 91-115.

https://doi.org/10.7202/037240ar

\section{Résumé de l'article}

Traduction, hétérogénéité, linguistique - En tant que traducteur américain de textes littéraires, je pense et réalise mes projets à partir d'un certain nombre d'hypothèses théoriques précises sur le langage et la textualité, hypothèses qui font ressortir les relations de pouvoir existant dans toute situation culturelle et qui donc ont des implications éthiques et politiques en traduction. Cependant, ces hypothèses, qui émanent de développements récents en théorie de la littérature et de la culture (notamment en sociologie poststructuraliste et postmarxiste) en Europe, vont à rencontre des approches axées sur la linguistique qui dominent aujourd'hui la recherche et la formation en traduction, et qui ont tendance à concevoir le langage, la textualité et donc la traduction comme des moyens de communication relativement « neutres ». Dans cet article, je décris ma conception de la traduction, analyse comment cette conception a informé mes récents projets de traduction - en matière tant de choix des textes étrangers que de mise en oeuvre de stratégies discursives et j'examine enfin en quoi elle diffère des approches axées sur la linguistique qui sont fondées sur la pragmatique et la linguistique du texte. Je n'insinue pas par là que ces approches doivent être abandonnées, mais qu'elles soient réenvisagées en fonction d'une orientation théorique et pratique différente qui à son tour, devra se remettre elle-même en question.
Tous droits réservés (C) TTR: traduction, terminologie, rédaction — Les auteurs, 1996
Ce document est protégé par la loi sur le droit d'auteur. L'utilisation des services d'Érudit (y compris la reproduction) est assujettie à sa politique d'utilisation que vous pouvez consulter en ligne.

https://apropos.erudit.org/fr/usagers/politique-dutilisation/ 


\section{Translation, Heterogeneity, Linguistics}

\section{Lawrence Venuti}

\section{A Theory}

As an American translator of literary texts I devise and execute my projects with a distinctive set of theoretical assumptions about language and textuality. Perhaps the most crucial is that language is never simply an instrument of communication employed by an individual according to a system of rules - even if communication is undoubtedly among the functions that language can perform. Following Deleuze and Guattari (1987), I rather see language as a collective force, an assemblage of forms that constitute a semiotic regime. Circulating among diverse cultural constituencies and social institutions, these forms are positioned hierarchically, with the standard dialect in dominance but subject to constant variation from regional or group dialects, jargons, clichés and slogans, stylistic innovations, nonce words, and the sheer accumulation of previous uses. Any language use is thus a site of power relationships because a language, at any historical moment, is a specific conjuncture of a major form holding sway over minor variables. Lecercle (1990) calls them the "remainder": the linguistic variations released by the remainder do not merely exceed any communicative act, but frustrate any effort to formulate systematic rules. The remainder subverts the major form by revealing it to be socially and historically situated, by staging "the return within language of the contradictions and struggles that make up the social" and by 
containing as well "the anticipation of future ones" (Lecercle, 1990, p. 182).

A literary text, then, can never simply express the author's intended meaning in a personal style. It rather puts to work collective forms in which the author may indeed have a psychological investment, but which by their very nature depersonalize and destabilize meaning. Although literature can be defined as writing created especially to release the remainder, it is the stylistically innovative text that makes the most striking intervention into a linguistic conjuncture by exposing the contradictory conditions of the standard dialect, the literary canon, the dominant culture, the major language. Because ordinary language is always a multiplicity of past and present forms, a "diachrony-within-synchrony" (Lecercle, 1990, pp. 201-208), a text can be no more than "a synchronic unity of structurally contradictory or heterogeneous elements, generic patterns and discourses" (Jameson, 1981, p. 141). Certain literary texts increase this radical heterogeneity by submitting the major language to constant variation, forcing it to become minor, delegitimizing, deterritorializing, alienating it. For Deleuze and Guattari such texts compose a minor literature, whose "authors are foreigners in their own tongue" (1987, p. 105). In releasing the remainder, a minor literature indicates where the major language is foreign to itself.

It is this evocation of the foreign that attracts me to minor literatures in my translation projects. I prefer to translate foreign texts that possess minority status in their cultures, a marginal position in their native canons - or that, in translation, can be useful in minoritizing the standard dialect and dominant cultural forms in American English. This preference stems partly from a political agenda that is broadly democratic: an opposition to the global hegemony of English. The economic and political ascendancy of the United States has reduced foreign languages and cultures to minorities in relation to its language and culture. English is the most translated language worldwide, but the least translated into (Venuti, 1995, pp. 12-14), a situation that identifies translating as a potential site of variation. 
To shake the regime of English, a translator must be strategic in selecting foreign texts and in developing discourses to translate them. Foreign texts can be chosen to redress patterns of unequal cultural exchange and to restore foreign literatures excluded by the standard dialect, by literary canons, or by ethnic stereotypes in the United States. At the same time, translation discourses can be developed to exploit the multiplicity and polychrony of American English, "conquer[ing] the major language in order to delineate in it as yet unknown minor languages" (Deleuze and Guattari, 1987, $\mathrm{p}$. 105). Foreign texts that are stylistically innovative invite the English-language translator to create idiolects striated with various dialects, registers and styles, inventing a collective assemblage that questions the seeming unity of standard English. The aim of minoritizing translation is "never to acquire the majority," never to erect a new standard or to establish a new canon, but rather to promote cultural innovation by proliferating the variables within English: "the minority is the becoming of everybody" (ibid., pp. $106,105)$.

My preference for minoritizing translation also issues from an ethical stance that recognizes the asymmetrical relations in any translation project. Translating can never simply be communication between equals because it is fundamentally ethnocentric. Not only are most projects initiated in the domestic culture, but the very function of translating is assimilation, inscribing the foreign text with domestic intelligibilities and interests. I follow Berman (1994, pp. 4-5) in judging bad any transiation that mystifies this inevitable domestication as an untroubled communicative act. Good translation is demystifying: it manifests in its own language the foreignness of the foreign text (Berman, 1985, p. 89). And this manifestation depends on introducing variations that alienate the domestic language and, since they are domestic, reveal the translation to be in fact a translation, distinct from the foreign text. Good translation is minoritizing: it releases the remainder by cultivating a heterogeneous discourse, opening up the standard dialect and literary canons to what is foreign to themselves, to the substandard and the marginal. This does not mean conceiving of a minor language as merely a dialect, which might wind up regionalizing or ghettoizing 
the foreign text, identifying it too narrowly with a specific cultural constituency (even though certain foreign texts and domestic conjunctures might well call for a narrow social focus). The point is rather to use a number of minority elements whereby "one invents a specific, unforeseen, autonomous becoming" (Deleuze and Guattari, 1987, p. 106). This translation ethics does not so much prevent the assimilation of the foreign text, as aim to signify the autonomous existence of that text behind (yet by means of) the assimilative processs of the translation.

Insofar as minoritizing translation relies on discursive hetereogeneity, it pursues an experimentalism that would seem to narrow its audience and contradict the democratic agenda I have sketched. Experimental form demands a high aesthetic mode of appreciation, the critical detachment and educated competence associated with the cultural elite, whereas the communicative function of language is emphasized by the popular aesthetic, which demands that literary form not only be immediately intelligible, needing no special cultural expertise, but also transparent, sufficiently realistic to invite vicarious participation (Bourdieu, 1984, pp. 4-5, 32-33; cf. Cawelti, 1976; Radway, 1984; Dudovitz, 1990). Yet translation that takes a popular approach to the foreign text isn't necessarily democratic. The popular aesthetic requires fluent translations that produce the illusory effect of transparency, and this means adhering to the current standard dialect while avoiding any dialect, register, or style that calls attention to words as words and therefore preempts the reader's identification. As a result, fluent translation may enable a foreign text to engage a mass readership, even a text from an excluded foreign literature, but it simultaneously reinforces the major language and its many other linguistic and cultural exclusions while masking the inscription of domestic values. Fluency in translation is assimilationist, presenting domestic readers a realistic representation inflected with their own codes and ideologies as if it were an immediate encounter with a foreign text and culture.

The heterogeneous discourse of minoritizing translation resists this assimilationist ethic by signifying the linguistic and 
cultural difference of the text - within the major language. The heterogeneity needn't be so alienating as to frustrate a popular approach completely; if the remainder is released at significant points in a translation that is generally readable, the reader's participation will be disrupted only momentarily. Moreover, a strategic use of minority elements can remain intelligible to a wide range of readers and so increase the possibility that the translation will cross the boundaries between cultural constituencies, even if it comes to signify different meanings in different groups. A minoritizing translator can draw on the conventionalized language of popular culture, "the patter of comedians, of radio announcers, of disc jockeys" (Lecercle, 1988, p. 37), to render a foreign text that might be regarded as elite literature in a seamlessly fluent translation. This strategy would address both popular and elite readerships by defamiliarizing the domestic mass media as well as the domestic canon for the foreign literature. Minoritizing translation can thus be considered an intervention into the contemporary public sphere, in which electronic forms of communication driven by economic interest have fragmented cultural consumption and debate: if "the public is split apart into minorities of specialists who put their reason to use non-publicly and the great mass of consumers whose receptiveness is public but uncritical" (Habermas, 1989, p. 175), then translating should seek to invent a minor language that cuts across cultural divisions and hierarchies. The goal is ultimately to alter reading patterns, compelling a not unpleasurable recognition of translation among constituencies who, while possessing different cultural values, nonetheless share a long-standing unwillingness to recognize it.

\section{A Project}

I was able to explore and test these theoretical assumptions in recent translations involving the nineteenth-century Italian writer I.U. Tarchetti (1839-1869). From the start the attraction was his minority status, both in his own time and now. A member of a Milanese bohemian subculture called the "scapigliatura" (from "scapigliato," meaning "dishevelled"), Tarchetti sought to deterritorialize the standard Tuscan dialect by using it to write in marginal literary 
genres: whereas the dominant fictional discourse in Italy was the sentimental realism of Alessandro Manzoni's historical novel, $I$ promessi sposi (The Betrothed), Tarchetti favored the Gothic tale and the experimental realism of French novelists like Flaubert and Zola (Venuti, 1995, pp. 160-161). The Italian standards against which Tarchetti revolted were not just linguistic and literary, but moral and political as well: whereas Manzoni posited a Christian providentialism, recommending conjugal love and resigned submission before the status quo, Tarchetti aimed to shock the Italian 'bourgeoisie, rejecting good sense and decency to explore dream and insanity, violence and aberrant sexuality, flouting social convention and imagining fantastic worlds where social inequity was exposed and challenged. He was admired by his contemporaries and, amid the cultural nationalism that characterized newly unified italy, was soon admitted to the canon of the national literature. Yet even if canonical he has remained a minor figure: he receives abbreviated, sometimes dismissive treatment in the standard manuals of literary history, and his work fails to resurface in the most provocative debates in Italian writing today.

A translation project involving Tarchetti, I realized, would have a minoritizing impact in English. His writing was capable of unsettling reigning domestic values by moving between cultural constituencies. In Fantastic Tales (1992) I chose to translate a selection of his work in the Gothic, a genre that has both elite and popular traditions. Initially a middlebrow literature in Britain (Ann Radcliffe), the Gothic was adopted by many canonical writers (E.T.A. Hoffmann, Edgar Allan Poe, Théophile Gautier) and has since undergone various revivals, some satisfying a highbrow interest in formal refinement (Eudora Welty, Patrick McGrath), others offering the popular pleasure of sympathetic identification (Anne Rice, Stephen King). Importing Tarchetti would cast these traditions and trends in a new light. For although ltaly is a recurrent motif in the Gothic, Fantastic Tales was the first appearance in English of the first Gothic writer in Italian.

Tarchetti wrote other texts that were equally flexible in their potential appeal. Under the title Passion (1994) I translated his novel 
Fosca, which mixes romantic melodrama with realism in an experiment variously suggestive of Madame Bovary and Thérèse Raquin. In English Fosca promised to straddle readerships as a rediscovered classic and as a historical romance, a foreign wrinkle on the bodice ripper. Yet as I was translating the Italian text I also learned that Tarchetti's novel had metamorphosed into a "tie-in," the source of an adaptation in a popular form: Stephen Sondheim and James Lapine's Broadway musical Passion (1994). Suddenly, a canonical Italian text, which in English might be expected to interest mainly an elite audience, was destined to have a much wider circulation.

What especially attracted me to Tarchetti's writing was its impact on the very act of translating: it invited the development of a translation discourse that submitted the standard dialect of English to continual variation. From the beginning I determined that archaism would be useful in indicating the temporal remoteness of the Italian texts, their emergence in a different cultural situation at a different historical moment. Yet any archaism had of course to be drawn from the history of English, had to signify in a current English-language situation, and would therefore release a distinctive literary remainder. With Fantastic Tales I assimilated the Italian texts to the Gothic tradition in British and American literature, modelling my syntax and lexicon on the prose of such writers as Mary Shelley and Poe. This is not to say that accuracy was sacrificed for readability and literary effect, but that insofar as any translating produces a domestic remainder, adding effects that work only in the domestic language and literature, I made an effort to focus them on a specific genre in English literary history. In minoritizing translation, the choice of strategies depends on the period, genre, and style of the foreign text in relation to the domestic literature and the domestic readerships for which the translation is written.

My version in fact follows the Italian quite closely, often resorting to calque renderings to secure a suitably archaic form of English. This excerpt from Tarchetti's tale, "Un osso di morto" ("A Dead Man's Bone"), is typical: 
Nel 1855, domiciliatomi a Pavia, m'era allo studio del disegno in una scuola privata di quella cittá; e dopo alcuni mesi di soggiomo aveva stretto relazione con certo Federico $M$. che era professore di patologia e di clinica per l'insegnamento universitario, e che morì di apoplessia fulminante pochi mesi dopo che lo aveva conosciuto. Era un uomo amantissimo delle scienze, della sua in particolare - aveva virtú e doti di mente non comuni - senonché, come tutti gli anatomisti ed i clinici in genere, era scettico profondamente e inguaribilmente - lo era per convinzione, né io potei mai indurlo alle mie credenze, per quanto ni vi adoprassi nelle discussioni appassionate e calorose che avevamo ogni giomo a questo riguardo. (Tarchetti, 1977, p. 65)

In 1855, having taken up residence at Pavia, I devoted myself to the study of drawing at a private school in that city; and several months into my sojourn, I developed a close friendship with a certain Federico M., a professor of pathology and clinical medicine who taught at the university and died of severe apoplexy a few months after I became acquainted with him. He was very fond of the sciences and of his own in particular - he was gifted with extraordinary mental powers except that, like all anatomists and doctors generally, he was profoundly and incurably skeptical. He was so by conviction, nor could I ever induce him to accept my beliefs, no matter how much I endeavored in the impassioned, heated discussions we had every day on this point. (Venuti, 1992, p. 79)

The archaism in the English passage is partly a result of its close adherence to the Italian, to Tarchetti's suspended periods and his period diction ("soggiorno," "apoplessia," "indurlo" are calqued: "sojourn," "apoplexy," "induce him"), In other cases, when a choice presented itself I took the archaism over current usage: for "né io potei mai," I used the inverted construction "nor could I ever" instead of the more fluent "and I could never"; for "per quanto mi vi adoprassi," I preferred the slightly antique formality of "no matter how much I endeavored" instead of a modern colloquialism, "no matter how hard I tried." 
The translation discourse of Fantastic Tales deviates noticeably from current standard English, yet not so much as to be incomprehensible to most contemporary readers. This was evident in the reception. I tried to shape readers' responses in an introductory essay that alerted them to the minoritizing strategy. The reviews made clear, however, that the archaism also registered in the reading experience, and not only by situating Tarchetti's tales in the remote past, but by implicitly comparing them to English-language Gothic and thus establishing their uniqueness. Most importantly, the archaism called attention to the translation as a translation without unpleasurably disrupting the reading experience. The Village Voice noticed the "atmospheric wording of the translations" (Shulman, 1992), while the New Yorker remarked that the "translation distills a gothic style never heard before, a mixture of Northern shadows and Southern shimmer" (1992, p. 119). Such reviews suggest that the formal experiment in the translation was most keenly appreciated by the cultural elite, readers with a literary education, if not academics with a specialist's interest. Yet Fantastic Tales also appealed to other constituencies, including fans of horror writing who are widely read in the Gothic tradition. A reviewer for the popular Gothic magazine, Necrofile, concluded that the book "is not so very esoteric that it has nothing to offer the casual reader," adding that "the connoisseur will undoubtedly be grateful for 'Bouvard' and 'The Fated," two tales that he felt distinguished Tarchetti as a "contributor to the rich tradition of nineteenth-century fantasy" (Stableford, 1993, p. 6).

Tarchetti's Fosca encouraged a more heterogeneous translation discourse because he pushed his peculiar romanticism to an alienating extreme, making the novel at once serious and parodic, participatory and subversive. The plot hinges on a triangle of erotic intrigue: the narrator Giorgio, a military officer engaged in an adulterous affair with the robust Clara, develops a pathological obsession with his commander's cousin, the repulsively emaciated Fosca, a hysteric who falls desperately in love with him. The themes of illicit love, disease, female beauty and ugliness, the pairing of the bourgeois ideal of domesticated femininity with the vampire-like femme fatale - these familiar conventions of the romantic macabre 
again prompted me to assimilate the Italian text to nineteenthcentury British literature, and I fashioned an English style from related novels like Emily Brontè's Wuthering Heights (1847) and Bram Stoker's Dracula (1897). Yet to match the emotional extravagance of Tarchetti's novel, I made the strain of archaism more extensive and denser, still comprehensible to a wide spectrum of contemporary American readers yet undoubtedly enhancing the strangeness of the text. The strategies developed in minoritizing translation depend fundamentally on the translator's interpretation of the foreign text, an interpretation that is attuned to its specifically literary qualities and constrained by an assessment of the domestic readerships the translator hopes to reach, a sense of their expectations and knowledge (of linguistic forms, literary traditions, cultural references).

I imagined my readership as primarily American, so the effect of strangeness could be obtained through Britishisms. I used British spellings ("demeanour," "enamoured," "apologised," "offence," "ensure"), even a British pronunciation: "a herb" instead of the American "an herb," which provoked an exasperated query from the publisher's copyeditor (Venuti, 1994, pp. 33, 95, 108, 157, 188, 22). Some archaisms resulted from calque renderings: "in tal guisa" became "in such guise"; "voler far le beffe della mia sconfitta," which in modern English might be translated as "wanting to make fun of my defeat," became "wanting to jest at my discomfiture"; "addio" became "adieu" instead of "goodbye"; and where Tarchetti's Rousseau-influenced thinking led him to write "amor proprio," I reverted to the French: "amour propre" (Tarchetti, 1971, pp. 140, 151, 148, 60; Venuti, 1994, pp. 146, 157, 154, 60). I adopted syntactical inversions characteristic of nineteenth-century English: "Mi basta di segnare qui alcune epoche" ("It was enough for me to note down a few periods [of my life] here") became "Suffice it for me to record a few episodes" (Tarchetti, 1971, p. 122; Venuti, 1994, p. 128). And I seized every opportunity to insert an antique word or phrase: "abbandonato" ("abandoned") became "forsaken"; "da cui" ("from which") became "whence"; "dirò quasi" ("I should almost say") became "I daresay"; "fingere" ("deceive") became "dissemble"; "fu indarno" ("It was useless") became "my 
efforts were unavailing" (Tarchetti, 1971, pp. 31, 90, 108, 134; Venuti, 1994, pp. 31, 92, 109, 140).

The more excessive archaism worked to historicize the translation, signalling the nineteenth-century origins of the Italian text. Yet to indicate the element of near-parody in Tarchetti's romanticism, I increased the heterogeneity of the translation discourse by mixing more recent usages, both standard and colloquial, some distinctly American. Occasionally, the various lexicons appeared in the same sentence.I translated "Egli non è altro che un barattiere, un cavaliere d'industria, una cattivo soggetto" ("He is nothing more than a swindler, an adventurer, a bad person") as "He is nothing but an embezzler, a con artist, a scapegrace," combining a modern American colloquialism ("con artist") with a British archaism ("scapegrace") that was used in novels by Sir Walter Scott, William Thackeray, George Meredith (Tarchetti, 1971, p. 106; Venuti, 1994, p. 110; OED). This technique immerses the reader in a world that is noticeably distant in time, but nonetheless affecting in contemporary terms - and without losing the awareness that the prose is over the top.

At a few points, I made the combination of various lexicons more jarring to remind the reader that he or she is reading a translation in the present. One such passage occurred during a decisive scene in which Giorgio spends an entire night with the ecstatic but ailing Fosca, who is dying for love of him:

Suonarono le due ore all'orologio.

- Come passa presto la notte; il tempo vola quando si

è felici - diss'ella. (Tarchetti, 1971, p. 82)

The clock struck two.

"How quickly the night passes; time flies when you're having fun," she said. (Venuti, 1994, p. 83)

The adage-like expression, "time flies when you're having fun," is actually a close rendering of the Italian (literally, "time flies when one is happy"). Yet in current American English it has acquired the 
conventionality of a cliché, used most often with irony, and with this remainder it can have multiple effects. On the one hand, the cliche is characteristic of Fosca, who both favors pithy statements of romantic commonplaces and is inclined to be ironic in her conversation; on the other hand, the abrupt appearance of a contemporary expression in an archaic context breaks the realist illusion of the narrative, interrupting the reader's participation in the characters' drama and calling attention to the moment in which the reading is being done. And when this moment is brought to mind, the reader comes to realize that the text is not Tarchetti's Italian, but an English translation.

Another opportunity to produce these effects occurred in one of Giorgio's introspective passages. When he describes his tendency toward extreme psychological states, he rationalizes, "Perché non mirare agli ultimi limiti?" ("Why not aim for the utmost bounds?"), which I translated as "Why not shoot for the outer limits?" (Tarchetti, 1971, p. 18; Venuti, 1994, p. 18). This rendering, also quite close to the Italian, nonetheless releases an American remainder: it alludes to space travel and, more specifically, to The Outer Limits, a 1960s television series devoted to science fiction themes. It too disrupts the engrossed reader by suddenly foregrounding the domestic culture where the reading experience is situated, introducing a popular code in what might otherwise be taken for an archaic literary text. But the allusion can simultaneously be absorbed into a highbrow interpretation: it is appropriate to the character, since it points to the fantastic nature of Giorgio's romanticism.

The discursive heterogeneity of my translation deviated not only from the standard dialect of English, but from the realism that has long dominated Anglo-American fiction. As a result, the reception varied according to the readership. The translation discourse found more favor with elite readers who were accustomed to formal experiments, as I gathered from interviews with colleagues, university-level teachers of British and American literature. Among readers who took the popular approach, responses depended on the degree of interest in Tarchetti's narrative. In an 
unsolicited letter, a member of an informal reading group in southern California complimented the publisher "on a lovely book," expressing particular appreciation for the "chilling drama of [Fosca's] death" (Heinbockel, 1995). Other popular readers wanted greater fluency to support their sympathetic identification. The review service, Kirkus, praised Passion precisely because it offered a thrilling experience: "Tarchetti's striking novel," the reviewer wrote, "has it all - obsession, deception, sex, death, and passion," noting as well that "both unwilling lover and disapproving reader are woven into [Fosca's] spell" (Kirkus Reviews, 1994). The translation, however, was judged to be "sometimes stiff, with an occasional jarring phrase."

My project was minoritizing, however, and Passion did in fact manage to reach different constituencies. This was due in large part to the serendiptious tie-in with a popular form, a Broadway musical by a leading contemporary composer. The publisher capitalized on this connection by using Sondheim and Lapine's title for the translation and by designing a striking cover to suggest the artwork that appeared in the many advertisements for the musical. Reviewers were drawn to the translation by the musical, which was routinely cited in reviews. Copies were sold in the lobby of the theater at performances, which continued for nearly a year. Within four months of publication, 6500 copies were in print. The translation did not make the bestseller list, but it was widely circulated for an Italian novel that had previously been unknown to English-language readers.

\section{A Polemic}

My translation theory and practice have led me to question the linguistics-oriented approaches that began emerging in translation studies during the 1960 s and currently constitute a prevalent trend, influencing both research and training throughout the world. These approaches, often based on pragmatics and text linguistics, set out from diametrically opposed assumptions about language and textuality which are often deliberately limited in their explanatory power and, in certain formulations, repressive in their normative 
principles. From my particular standpoint as a translator, they project a conservative model of translation that would unduly restrict its role in cultural innovation and social change. Nonetheless, I do not wish to suggest that such approaches be abandoned, but rather that they be reconsidered from a different theoretical and practical orientation - one that will in turn be forced to rethink itself.

The key assumption in the linguistics-oriented approaches is that language is an instrument of communication employed by an individual according to a system of rules. Translation is then theorized on the model of Gricean conversation, in which the translator communicates the foreign text by cooperating with the domestic reader according to four "maxims": "quantity" of information, "quality" or truthfulness, "relevance" or consistency of context, and "manner" or clarity (Grice, 1989, pp. 26-27; cf. Hatim and Mason, 1990, pp. 62-65, 95-100; Baker, 1992, pp. 225-254; Neubert and Shreve, 1992, pp. 75-84). Grice interestingly admits that language is much more than cooperative communication when he proceeds to argue that the maxims are routinely "flouted" in conversation, "exploited" by interlocutors to open up a substratum of "implicature," such as irony (Grice, 1989, pp. 30-31; Lecercle, 1990 , p. 43). In the case of translation, linguistics-oriented theorists have construed implicature as a feature of the foreign text that reveals a difference between the foreign and domestic cultures, usually a gap in the domestic reader's knowledge for which the translator must somehow compensate. Yet communication (or even compensation) doesn't quite describe the translator's remedy, which seems more like ventriloquism, a rewriting of the foreign text according to domestic intelligibilities and interests: "Information essential to the success of conversational implicatures should be included in the text if the translation is to be coherent and sensible" (Thomson, 1982, p. 30; Thomson's emphasis).

The problem is not this rewriting, which translators do routinely, myself included, but rather the way it is understood. Neither the conversational maxims nor implicature can account for the working of the remainder in any translation; on the contrary, they effectively repress it. The domestic linguistic forms that are 
added to the foreign text to make it "coherent and sensible" in the domestic culture inevitably exceed any intention to convey a message (and so violate the maxim of quantity) because these forms are at once collective and variable in significance, sedimented with the different functions they perform in different constituencies and institutions. If according to Gricean implicature translation is a process of exploiting the maxims of the domestic linguistic community (Baker, 1992, p. 238), the remainder exposes the fact that maxims can differ within any community, and a translation discourse, even when cooperatively described in an introductory statement, can divide readerships. To compensate for an implicature in the foreign text, a translator may add footnotes or incorporate the supplementary material in the body of the translation, but either choice adheres to a different maxim of quantity that addresses a different constituency: adding footnotes to the translation can narrow the domestic audience to a cultural elite since footnotes are an academic convention. The remainder likewise threatens the maxim of truth, or the "virtual reality" created in the translation (Neubert and Shreve, 1992, p. 79), because the variables it contains can introduce a competing truth or break the realist illusion. Furthermore, insofar as the remainder consists of discursive heterogeneity, any translation is likely to contain shifts between dialects, codes, registers and styles that violate the maxims of relevance and manner by deviating from contexts and risking multiple meanings and obscurity. In repressing the remainder, a translation theory based on Gricean conversation leads to fluent strategies that mystify their domestication of the foreign text while reinforcing dominant domestic values - notably the major language, the standard dialect, but possibly other cultural discourses (literary canons, ethnic stereotypes, an elite or a popular aesthetic) inscribed in the translation to render a foreign implicature.

Linguistics-oriented approaches, then, would seem to block the ethical and political agenda I envisaged for minoritizing translation. Grice's cooperative principle assumes an ideal speech situation in which the interlocutors are on an equal footing, autonomous from cultural differences and social divisions. Yet the remainder, the possibility for variation in any linguistic conjuncture, 
means that the translator works in an asymmetrical relationship, always cooperating more with the domestic than the foreign culture and usually with one constituency among others. In the shift from conversation to translation, as one linguistics-oriented theorist has incisively observed, the cooperative principle itself is thrown into contradiction, shown to be exclusionary: "Grice's maxims seem to reflect directly notions which are known to be valued in the Englishspeaking world, for instance sincerity, brevity, and relevance" (Baker, 1992, p. 237). More, when made the basis of literary translating, the conversational maxims require that the translator not frustrate domestic expectations in the choice of foreign texts and in the development of discourses to translate them. An American literary translator will thus maintain existing canons for domestic and foreign literatures and cultivate a homogeneous discourse by excluding what is foreign to it, the substandard and the marginal. Yet to redress the global hegemony of English, to interrogate American cultural and political values, to evoke the foreignnness of the foreign text, an American literary translator must not be cooperative, but challenging, not communicative, but provocative. Grice's pacific maxims encourage translation that strengthens current reading patterns, both elite and popular, whereas Deleuze and Guattari's agonistic concept of language encourages translation that seeks to revise those patterns by crossing the cultural boundaries between them.

The limitations of linguistics-oriented approaches are perhaps most clear with literary translation in the broad sense, not only literature but texts in the various genres and disciplines that constitute the human sciences, both fiction and nonfiction, and in electronic as well as print media. The minoritizing translator, motivated to release the domestic remainder by working with a stylistically innovative text, will not abide by the cooperative principle. Nor will a majoritarian reader who strongly resists any discursive heterogeneity that makes a reading experience less participatory and more critically detached - or, in other words, that aims to modulate between an elite and popular aesthetic. The Gricean model of translation holds out the hope that "readers' versions of reality, their expectations, and their preferences can be 
challenged without affecting the coherence of a text, provided the challenge is motivated and the reader is prepared for it" (Baker, 1992, p. 249). Unfortunately, the mixed reception that met my translation of Tarchetti's Passion indicates that such a challenge, even though rationalized explicitly, can indeed meet with uncooperative readers. Yet Passion showed that minoritizing translation can still move between cultural constituencies precisely because its discursive heterogeneity is able to support diverse notions of coherence that circulate among different constituencies. Current linguistics-oriented approaches lack not only the theoretical assumptions to conceptualize and execute such literary translation projects, but the methodological tools to analyze them.

Technical translation would seem to be better suited to theorization according to Grice's maxims. In fact, translators of scientific, commercial, legal, and diplomatic documents will be bound, by their contracts or by the conditions of their employment in agencies, to honor those maxims because the texts they translate give priority to communication and to the production of a particular effect in the world. The translation of technical documents (e.g. scientific research, product warranties, birth certificates, peace treaties) usually occurs in such narrowly defined situations, with standardized terminologies and specialized readerships, that it escapes the continual variation in natural languages: any implicature in these documents tends to be purely conventional, hardly brought into existence by the flouting that occurs in conversation. The ethics I formulated for translating literary texts, then, must be revised to accommodate the different conditions of technical translation: here good translating adheres to the conventions of the field or discipline that the document is designed to serve. This is a purely functional standard, which will eventually force the evaluation of the translated text to take into account its social purpose and effects.

Yet even with technical translation certain situations and projects may arise to warrant a violation of a Gricean maxim or even the cooperative principle itself. In translating advertisements, a translator may find it useful to frustrate domestic expectations of a foreign culture, to depart from reigning ethnic stereotypes, so as 
to invest a foreign product with a distinctively domestic charisma, thereby increasing the effectiveness of the advertising copy in translation. In interpreting for geopolitical negotiations, a translator may wish to remove satirical innuendo, a kind of implicature that would obstruct communication by creating antagonism between the negotiators. In conference and court interpreting, a translator may correct grammatical errors, avoid reproducing hesitations and verbal slips, and delete culture-specific formulas, all to increase domestic intelligibility, interest, even sympathy (Morris, 1995). In each of these cases, the translator not only violates some conversational maxim, but raises the question of whether the translation practice can accurately be called communication as opposed to provocation, naturalization or palliation. And clearly the translator's violations will carry ethical and political implications, not only in their usefulness to the field that the translation is designed to serve, but also in their concern with the larger issues of peaceful international relations and the fair admini-stration of justice.

The most worrisome tendency in linguistics-oriented approaches is their promotion of scientific models. Because language is defined as a set of systematic rules autonomous from cultural and social variation, translation is studied as a set of systematic operations autonomous from the cultural and social formations in which they are executed. Translation theory then becomes the synchronic description of two ideal objects: the linguistic practices that the translator employs to render the foreign text, like calque or "compensation" (see, for example, Harvey, 1995), and the "typical situations in which certain kinds of translation are preferred" (Neubert and Shreve, 1992, pp. 34, 84-88). Yet insofar as such approaches exclude the theory of the remainder, they purify translation practices and situations of their social and historical variables, leaving literary and technical translators alike unequipped to reflect on the cultural meanings, effects, and values produced by those practices.

Without a theory of the remainder, a description of translation practices can't explain how text-specific features produce different effects according to different reader motivations and 
cultural conventions. And to explain how my renderings in Passion divided domestic readerships, a social theory of cultural value (e.g. Bourdieu) is necessary. The important point is that translators should be able to provide such explanations as a rationale for choosing between different practices and even different projects, i.e., whether to contract for them in the first place. Otherwise descriptions of textual practices are likely to encourage mechanical, unreflective translating that is not concerned with its value - or only with its utilitarian and economic as opposed to cultural and political values. "The scientific model taking language as an object of study," remark Deleuze and Guattari, "is one with the political model by which language is homogenized, centralized, standardized, becoming a language of power, a major or dominant language" (Deleuze and Guattari, 1987, p. 101). Yet by repressing the heterogeneity of language, the scientific model prevents translators from understanding and evaluating what their practices admit and exclude, and what social relations those practices make possible.

My recommendation, then, is that linguistics-oriented approaches be qualified and supplemented by the theory of the remainder and the social and historical thinking that it demands of translators. There can be no question of choosing between these two approaches - between adhering to the constants that linguistics extracts from language or placing them in continuous variation because language is a continuum of dialects, registers, styles, and discourses positioned in a hierarchical arrangement and developing at different speeds and in different ways. Translation, like any language use, is a selection accompanied by exclusions, an intervention into the contending languages that constitute any historical conjuncture, and translators will undertake diverse projects, some that require adherence to the major language, others that require minoritizing subversion. Pragmatics and text linguistics can be useful in training translators and analyzing translations, provided that the descriptions devised by these approaches are joined to a theory of the heterogeneity of language and its implication in cultural and political values. Thus, May relies on Gricean conversation to analyze an English translation of a Russian novel, revealing how the translator did not compensate for an implicature 
in the foreign text and wound up omitting a self-reflexive register in the narrative (May, 1994, pp. 151-152). Yet she explains this omission by situating it in the Anglo-American translation tradition, where the dominance of fluent strategies results in "clashing cultural attitudes toward narrative and style in the original and target languages," as well as a "struggle between translator and narrator for control of the text's language" (ibid., p. 59).

In searching for a common ground between the linguisticsoriented approaches and what I shall call the materialist orientation made possible by the remainder, it seems important to question the notion that translation theory and practice can be understood and advanced simply by studying textual evidence. To yield any insights, textual features must still be processed on the basis of particular theoretical assumptions - without this processing they can't be called "evidence" of anything - and these assumptions should be submitted to on-going scrutiny and revision. Neubert and Shreve's call for an "empirical approach to translation studies" (1992, p. 33), despite their insistence to the contrary, will not produce inferences verified by observing actual translation practices, but deductions from the idealized concepts of pragmatics and text linguistics that constitute their guiding principles - Grice and Beaugrande and Dressler (1981) applied to translation. As a result, the inferences made from this approach ultimately serve to confirm assumptions about language and textuality that appear reductive and conservative, especially from the standpoint of an American literary translator. Studying the remainder in translation does not entail abandoning the empirical description of recurrent textual practices and typical situations. It rather offers a way to articulate and clarify - in terms that are at once textual and social - the ethical and political dilemmas that translators face when working in any situation. Our aim should be research and training that produces readers of translations and translators who are critically aware, not predisposed toward norms that exclude the heterogeneity of language. 


\section{References}

BAKER, Mona (1992). In Other Words: A Coursebook on Translation. London and New York, Routledge.

BEAUGRANDE, Robert-Alain de, and Wolfgang Ulrich Dressler (1981). Introduction to Text Linguistics. London and New York, Longman.

BERMAN, Antoine (1985). "La traduction de la lettre, ou l'auberge du lontain." Les Tours de Babel: Essais sur la traduction. Mauvezin, Trans-Europ-Repress.

(1992). The Experience of the Foreign: Culture and Translation in Romantic Germany. Trans. S. Heyvaert. Albany, State University of New York Press.

BOURDIEU, Pierre (1984). Distinction: A Social Critique of the Judgement of Taste. Trans. Richard Nice. Cambridge, Massachusetts, Harvard University Press.

CAWELTI, John (1976). Adventure, Mystery, and Romance: Formula Stories as Art and Popular Culture. Chicago, University of Chicago Press.

DELEUZE, Gilles, and Félix Guattari (1987). A Thousand Plateaus: Capitalism and Schizophrenia. Trans. Brian Massumi. Minneapolis, University of Minnesota Press.

DUDOVITZ, Resa (1990). The Myth of Superwoman: Women's Bestsellers in France and the United States. London and New York, Routledge.

GRICE, Paul (1989). Studies in the Way of Words. Cambridge, Massachusetts, Harvard University Press. 
HABERMAS, Jutrgen (1989). The Structural Transformation of the Public Sphere: An Inquiry into a Category of Bourgeois Society. Trans. Thomas Burger with Frederick Lawrence. Cambridge, Massachusetts, MIT Press.

HARVEY, Keith (1995). "A Descriptive Framework for Compensation." The Translator: Studies in Intercultural Communication, I:I.

HATIM, Basil, and Ian Mason (1990). Discourse and the Translator. London, Longman.

HEINBOCKEL, Madeline (1995). Letter to Mercury House. 9 February.

JAMESON, Frederic (1981). The Political Unconscious: Narrative as a Socially Symbolic Act. Ithaca, New York, Cornell University Press.

KIRKUS Reviews (1994). Review of Venuti (1994). 1 June.

LECERCLE, Jean-Jacques (1988). "The Misprison of Pragmatics: Con-ceptions of Language in Contemporary French Philosophy." In Contemporary French Philosophy. Ed. A. Phillips Griffiths. Cambridge, Cambridge University Press.

(1990). The Violence of Language. London and New York, Routledge.

MAY, Rachel (1994). The Translator in the Text: On Reading Russian Literature in English. Evanston, Illinois, Northwestern University Press.

MORRIS, Ruth (1995). "The Moral Dilemmas of Court Interpreting." The Translator: Studies in Intercultural Communication, I:1. 
NEUBERT, Albrecht, and Gregory Shreve.(1992). Translation as Text. Kent, Ohio, Kent State University Press.

The New Yorker (1992). "Books Briefly Noted." 2 November.

RADWAY, Janice (1984). Reading the Romance: Women, Patriarchy, and Popular Literature. Chapel Hill, University of North Carolina Press.

SHULMAN, Polly (1992). "Faux Poe." Village Voice. 20 October.

SONDHEIM, Stephen, and James Lapine (1994). Passion: $A$ Musical. New York, Theater Communications Group.

STABLEFORD, Brian (1993). "How Modern Horror Was Born." Necrofile. Winter.

TARCHETTI, I.U. (1971). Fosca. Torino, Einaudi.

Guanda.

(1979). Racconti fantastici. Ed. Neuro Bonifazi. Milano,

THOMSON, G. (1982). "An Introduction to Implicature for Translators." Notes on Translation, 1.

VENUTI, Lawrence, ed. and trans. (1992). I.U. Tarchetti, Fantastic Tales. San Francisco, Mercury House.

trans. (1994). I.U. Tarchetti, Passion: A Novel. San Francisco, Mercury House.

(1995). The Translator's Invisibility: A History of Translation. London and New York, Routledge. 
ABSTRACT: Translation, Heterogeneity, Linguistics - As an American translator of literary texts I devise and execute my projects with a distinctive set of theoretical assumptions about language and textuality, assumptions that highlight the power relations in any cultural situation and that therefore carry ethical and political implications for translation. Yet these assumptions, derived from recent European developments in literary and cultural theory (notably poststructuralism and postmarxist sociology), run counter to the linguistics-oriented approaches that currently dominate translation research and translator training, and that tend to construe language, textuality, and hence translation as relatively value-free means of communication. My article describes my conception of translation, considers how it has informed my recent translation projects - both the selection of foreign texts and the development of discursive strategies - and then examines its differences to linguistics-oriented approaches that are based on pragmatics and text linguistics. My aim is not to suggest that such approaches be abandoned, but rather that they be reconsidered from a different theoretical and practical orientation - one that will in turn be forced to rethink itself.

RÉSUMÉ: Traduction, hétérogénéité, linguistique - En tant que traducteur américain de textes littéraires, je pense et réalise mes projets à partir d'un certain nombre d'hypothèses théoriques précises sur le langage et la textualité, hypothèses qui font ressortir les relations de pouvoir existant dans toute situation culturelle et qui donc ont des implications éthiques et politiques en traduction. Cependant, ces hypothèses, qui émanent de développements récents en théorie de la litterature et de la culture (notamment en sociologie poststructuraliste et postmarxiste) en Europe, vont à l'encontre des approches axées sur la linguistique qui dominent aujourd'hui la recherche et la formation en traduction, et qui ont tendance à concevoir le langage, la textualité et donc la traduction comme des moyens de communication relativement «neutres». Dans cet article, je décris ma conception de la traduction, analyse comment cette conception a informé mes récents projets de traduction - en matière tant de choix des textes étrangers que de mise en cuvre de stratégies discursives - et j'examine enfin en quoi elle diffère des approches 
axées sur la linguistique qui sont fondées sur la pragmatique et la linguistique du texte. Je n'insinue pas par là que ces approches doivent être abandonnées, mais qu'elles soient réenvisagées en fonction d'une orientation théorique et pratique différente - qui, à son tour, devra se remettre elle-même en question.

Lawrence Venuti: Department of English, Temple University, Anderson Hall (022-29), Philadelphia, Pennsylvania 19122, USA 